\title{
DAMPAK TEKNOLOGI INFORMASI TERHADAP PERUBAHAN STRUKTUR KOTA DAN SISTEM TRANSPORTASI
}

\author{
Na n d i \\ cepnandi@gmail.com \\ Jurusan Pendidikan Geografi FPIPS UPI \\ Jl. Setiabudi No 229 Bandung 40154
}

\begin{abstract}
Currently, wireless communications brings a new dimension in human interaction. The process of this interaction will be more conducted by human in the future without depending on the location of comunicating. It is still difficult to predict how quickly humans can adapt to this technology. As well as the effectiveness of the use of SMS (short messages service) which is a new phenomenon, need some time to expand knowledge about how to use them. Thus, a wireless telecommunications can bring a big influence to human behavior. Advances in technology will shape and continue to shape the economic and physical development of urban areas. New telecommunications technology and urban economic development, can changing roles and patterns of physical development. Many big cities lose its function as the headquarters or manufacturing centers because of the intensive information activities such as customer service centers and research and development laboratory. Furthermore, information technology which is progress very rapidly forming a new challenge in finance, health and education. It became the basis of the needs in urban areas also play a role in trade and culture in urban areas (Moss, 1988). This paper will try to present the impact caused by developments information technology to change the urban structure and urban transportation systems.
\end{abstract}

Keywords: Information Technology, Transportation, Urban Structures

\section{PENDAHULUAN}

Ada dua tradisi dalam teori perencanaan yang membahas masalah teknologi informasi hubungannya dengan struktur kota dan transportasi, yaitu: the deconcentration and economic-restructuring schools. Tradisi deconcentration school, menyatakan bahwa teknologi informasi dan struktur kota merupakan tahapan terbaru dalam analis konsekwensi inovasi teknologi komunikasi dan dampaknya terhadap transportasi, yang menimbulkan permasalahan baru dalam akses secara geografis. Sedangkan tradisi restructuring school, lebih menekankan teorisasi pada transformasi produksi secara social-teknis, kelembagaan dan kehidupan sehari-hari. Walaupun berbeda fokus pembahasan, tetapi kedua tradisi ini sama-sama membahas mengenai kemungkinan terjadinya desentralisasi atau sentralisasi dan mencoba mengidentifikasi dampak dispersi kawasan perkotaan yang dihubungkan dengan teknologi informasi dan masyarakat yang masih tergantung pada kendaraan untuk menunjang aktivitasnya. 
Beberapa literatur menunjukkan optimisme bahwa teknologi informasi dapat menurunkan kebutuhan perjalanan (travel demand) karena diyakini dengan teknologi informasi masyarakat bisa mengakses informasi dimanapun tanpa perlu menghasilkan perjalanan (trips). Beberapa penelitian telah dilakukan untuk menganalisa dampak teknologi informasi ini terhadap kehidupan sehari-hari yang turut mempengaruhi bangkitan pergerakan di suatu kota. Banyak penelitian menunjukkan bahwa teknologi informasi mampu merubah struktur kota. Namun demikian, sampai saat ini belum ada bukti empiris mengenai struktur kota seperti apa yang dihasilkan oleh perkembangan teknologi informasi tersebut. Pemodelan yang telah banyak dilakukan cenderung masih belum bisa memberikan jawaban karena banyak melakukan penyederhanaan dan didasarkan pada asumsi yang kurang kuat. Sementara itu pengalaman empiris yang menunjukkan struktur kota yang terbentuk akibat kemajuan teknologi informasi belum bisa ditemui karena perubahan struktur kota akan memakan waktu yang sangat panjang dan tidak dipengaruhi oleh faktor tunggal.

Di sisi lain pengaruh gerakan perencanaan yang dikenal sebagai new urbanism, transit-oriented development, dan perencanaan neotraditional mencoba memberikan solusi masalah transportasi melalui perubahan struktur kota dengan penataan kawasan perkotaan. Biasanya para arsitek dan perencana yang menyampaikan ide ini sangat berhati-hati dengan menekankan banyaknya faktor yang perlu dipertimbangkan untuk memperoleh hasil pemecahan masalah lalu lintas dengan diterapkannya konsep jaringan lokal, traffic calming, integrasi guna lahan dan kepadatan - tetapi literatur dan rencana mengenai penerapan konsep ini dan keyakinan akan kemampuannya untuk menurunkan kebutuhan perjalanan terus berkembang. Masalahnya dampak terhadap lalu lintas akibat rencana kota yang baru ini umumnya tidak bisa didefinisikan dan juga tidak jelas apakah perencana kota tersebut mengerti benar alasan mengapa rencana tersebut bisa memberi pemecahan masalah lalu lintas mengingat terlalu banyaknya penyederhanaan dan elemen yang tidak dipertimbangkan dalam perencanaan tersebut.

Debat mengenai apakah telekomunikasi akan mendorong terjadinya dispersi kawasan perkotaan secara spasial atau akan menyebabkan terjadinya konsentrasi kegiatan, telah berlangsung lebih dari 2 dekade. (Johnson 1968; Berry 1973; Gottman 1977; Abler 1977; Moayer 1977). Kemajuan teknologi seringkali oleh media dipopulerkan sebagai jaman tanpa jarak, berkembang menjadi penelitian ilmiah yang menggunakan determinan dan asumsi dispersi sederhana, hingga penilaian secara empiris melalui hipotesa efek dispersi dan konsentrasi kawasan perkotaan.

Restrukturisasi dalam bidang ekonomi dan penataan ruang dapat terjadi sebagai hasil dari: 1) perubahan teknologi, sebagai hasil dari transformasi modal produksi; dan 2) peran negara dalam membentuk kondisi pertumbuhan ekonomi (akumulasi).

Beberapa literatur dan penelitian mengenai sinergi spasial antara teknologi informasi dan transportasi, perubahan organisasi dan perkembangan ekonomi, mengindikasikan: 1) adanya perubahan bentuk perkotaan menjadi lebih terkoneksi secara global (King 1990; Sassen 2001, 1994, 1991; Castells 1996b; Hall 2002, 1997; Salomon 1996b; Graham and Marvin 1996); 2) tidak ada batas administrasi dan lebih terfragmentasi (Castells 1996a; Graham and Marvin 2000); 3) secara morfologi lebih polisentris dan kompleks (Guillespie 1992; Clark and Kuijpers-Linde 1994; Office of Technology Assessment [OTA] 1995; Kasarda 2000); 4) dispersi secara cepat pada operasional rutin (baik dalam hirarki perkotaan maupun dispersi ke luar negeri)(Hackler 2000; Sassen 2001); 5) re-konsentrasi pengetahuan intensif pada lingkungan dan inti 
metropolitan (OTA1995; Amirahmadi and Wallace 1995; Storper 1997; O'Kelly and Grubesic 2002).

Baik teknologi informasi maupun penataan kawasan sama-sama merubah struktur kota. Penataan kawasan perkotaan merubah struktur kota dengan bentuk yang mudah diamati, namun tidak demikian halnya dengan teknologi informasi. Kedua sebab terjadinya perubahan struktur kota ini ternyata tidak menjamin akan menurunkan kebutuhan perjalanan masyarakat kota tersebut. Beberapa literatur mengemukakan sanggahan terhadap pernyataan bahwa kebutuhan perjalanan dapat diturunkan dengan merubah struktur kota.

\section{HASIL DAN PEMBAHASAN}

\section{Dampak Terhadap Struktur Kota}

Telekomuting mempengaruhi tataguna lahan di perkotaan. Perilaku perjalanan akan berubah dan jumlah perjalanan diharapkan dapat menurun. Banyak orang akan membeli rumah pada daerah yang lebih menarik dan jauh dari kawasan perkotaan (Hjorthol, 2002). Penyebaran perusahaan dan perkantoran diharapkan mampu menurunkan jarak perjalanan ke tempat kerja. Sama halnya dengan adanya penurunan intensitas keterkaitan antara kekuatan tenaga kerja dan aktivitas ekonomi yang diukur berdasarkan perubahan frekuensi perjalanan (Kumar, 1989). Masalahnya, efek urban sprawl dari telekomuting tidak bisa diamati secara langsung beberapa tahun setelah teleworking dimulai. Telework berpotensi merevitalisasi perkotaan yang ada dengan memberi kesempatan pada masyarakat untuk tinggal dan bekerja pada satu lingkungan yang sama. (Nilles, 1996).

Pada beberapa kasus, jarak bukan lagi merupakan masalah jika informasi bisa disampaikan melalui jaringan telekomunikasi. Ruang dan tempat tidak lagi dipengaruhi oleh faktor jarak dan waktu. Konsep terbaik mengenai perubahan peranan ruang, tempat, jarak dan waktu pada jaman informasi dinyatakan oleh Castells (1996) yang memperkenalkan konsep "space of flows and timeless time".

Kebanyakan ilmuwan berpendapat bahwa teknologi informasi memiliki dampak centralizing dan dampak decentralizing. Dampak yang timbul tergantung pada bagaimana aplikasi teknologi informasi tersebut. Castells (2001) berpendapat bahwa khusus untuk internet, akan meningkatkan peran kota besar sebagai lokasi industri dan jasa. Alasan dasar adanya konsentrasi metropolitan adalah kota besar memiliki potensi melakukan inovasi teknologi yang lebih tinggi. Di lain sisi, Mitchell (1999), dan Weiner dan Brown (1997) menyatakan bahwa perbedaan antara kota dan daerah sekitarnya akan menurun karena pelayanan yang sama akan diperoleh pula oleh daerah perdesaan dan banyak orang akan pindah ke daerah perdesaan karena menginginkan lingkungan yang lebih baik dan harga rumah yang lebih murah. Weiner and Brown menyebutkan daerah ini sebagai "rurbania".

Dampak kemajuan teknologi informasi juga menyebabkan terjadinya konsentrasi industri dan jasa secara global. Perusahaan akan memiliki fasilitas untuk mencapai lokasi tanpa batas geografis, untuk membuat produk dan jasa baru, mengirimkan, menerima dan memproses informasi hanya dari beberapa titik di bumi ini. Hal ini dibuktikan dengan adanya peningkatan jumlah perusahaan multinasional yang meningkatkan konsentrasi fungsi kantor pusat di beberapa kota utama saja. Kota tumbuh dengan fungsi hanya sebagai pusat informasi internasional dan penanaman 
modal seperti New York, Los Angeles, London, Tokyo, Singapore dan Hong Kong (Moss, 1984).

Banyak ilmuwan seperti Mitchell (1999) dan Kotkin (2000), menyatakan bahwa nilai tempat akan tetap, tetapi nilai jarak akan menurun. Dalam simposium teleworking pada pertengahan 1990an, beberapa responden menyatakan sangat puas dengan sistem bekerja di rumah dan mayoritas teleworkers tinggal dalam keluarga tunggal di daerah suburban dan hanya 20\% dari mereka yang pindah ke luar kota (Tayyaran, Khan and Anderson, 2003). Teknologi informasi memberi kebebasan bagi penentuan lokasi sehingga karakteristik khusus suatu tempat menjadi penting dalam memilih lokasi untuk suatu aktivitas. Dua hal utama yang akan berubah adalah penentuan lokasi perkantoran dan penentuan lokasi permukiman. Faktor yang mempengaruhi penentuan lokasi dalam era informasi ditunjukkan pada tabel 1.

Tabel 1. Faktor Kunci Penentuan Lokasi dalam Era Teknologi Informasi

\begin{tabular}{l|l}
\hline \multicolumn{1}{c|}{ Residential Location } & \multicolumn{1}{c}{ Office Location } \\
\hline - Household characteristics & - Nature of business \\
- Housing cost & - Distributed work \\
- Size of dwelling & - Agglomeration economies \\
- Availability of information & - Land cost and availability/office cost \\
technologies and services & - Availability of human resources \\
& - Availability of enabling information \\
& technologies \\
Telecommuting & Telecommuting \\
Intelligent transportation systems & Transportation: accessibility, travel \\
Travel time to work and reliability & time, reliability \\
Quality of education & Intelligent transportation systems \\
Travel time to school and reliability & Parking \\
Quality of life-outdoor recreational & Quality of life \\
opportunities & \\
\hline Sumber: Tayyaran, Khan and Anderson, 2003.
\end{tabular}

Baik perubahan penentuan lokasi perkantoran maupun perubahan penentuan lokasi permukiman memiliki pengaruh terhadap struktur kota. Prediksi struktur kota akibat teknologi informasi yang mempengaruhi penentuan lokasi diuraikan sebagai berikut.

\section{Pengaruh Perubahan Penentuan Lokasi Perkantoran}

Kemajuan teknologi informasi dapat merubah struktur spasial perkotaan dan pengembangannya. Inovasi dalam teknologi informasi dan perbaikan sistem transportasi dapat meningkatkan fleksibilitas dalam memilih lokasi permukiamn. Fleksibilitas ini akan merubah konfigurasi kawasan perkotaan dan bentuk konfigurasi yang mungkin timbul merupakan pertanyaan yang harus dijawab oleh para peneliti. Biasanya akan ada penawaran tempat bermukim pada lokasi bisnis yang mereka pilih dan juga ada pertimbangan tentang memilih lokasi kantor dan para pekerjanya (Tayyaran, Khan and Anderson, 2003).

"Dulu pekerjaan memiliki dampak yang besar terhadap pemilihan lokasi perumahan. Situasi ini akan berubah. Masyarakat bisa bekerja menggunakan telekomunikasi dimanapun. Cuaca dan lingkungan yang baik, standar fasilitas dan pelayanan yang mencukupi serta alasan lainnya bisa menjadi criteria utama dalam memilih lokasi. Biasanya fasilitas telekomunikasi yang baik harus tersedia (Talvetie, 2003). Mitchell (1999) berargumen bahwa revolusi digital akan membawa rumah dan kantor menjadi 
sesuatu yang tidak perlu dipisahkan. Rumah harus direncanakan dapat difungsikan baik untuk bekerja maupun tempat tinggal (Mitchell, 1999; Moss and Townsend, 2000)" (Talvetie, 2003).

\section{Pengaruh Perubahan Penentuan Lokasi Permukiman}

Shen, Qing. 2000. Dalam New Telecommunications and Residential Location Flexibility (Environment and Planning A 32, 8: 1445-63) melakukan simulasi dampak subtitusi transportasi terhadap struktur kota yang dihubungkan dengan penggunaan telekomunikasi pada hypothetical metropolitan area. Penelitian ini mengasumsikan bahwa telekomunikasi meningkatkan fleksibilitas lokasi permukiman, sebagaimana menurunkan kebutuhan perjalanan, meningkatkan kecepatan interaksi spasial atau kombinasi keduanya. Dengan menggunakan tiga skenario dalam mensubtitusi perjalanan oleh telekomunikasi dan menetapkan kestabilan struktur kota eksisting, ternyata fleksibilitas lokasi tidak berubah secara signifikan bila subtitusi dilakukan pada tingkat yang rendah. Kesimpulan penelitian ini menunjukkan bahwa peningkatan fleksibilitas lokasi permukiman akan mendorong urban sprawl atau bisa dijadikan alat untuk para perencana dalam mendorong pertumbuhan kota pada lokasi yang diinginkan.

Fleksibilitas lokasi permukiman di era telekomunikasi menunjukkan bahwa rumah yang tidak memiliki kapabilitas telekomunikasi akan lebih menghambat peningkatan subtitusi transportasi oleh telekomunikasi. Fleksibilitas lokasi permukiman menjadi sangat terbatas bagi rumah yang hanya mengandalkan transportasi umum sebagai satusatunya akses. Hasil simulasi pada table berikut menunjukkan zona 1 (pusat kota) merupakan satu-satunya lokasi yang memungkinkan rumah tanpa akses telekomunikasi tersebut bisa mendapat akses transportasi yang memadai. Karena rumah yang tidak memiliki akses telekomunikasi biasanya memiliki kondisi ekonomi yang rendah maka simulasi tersebut menunjukkan bahwa akan terjadi konsentrasi kemiskinan di pusat kota pada abad informasi.

Tabel 2 Perbandingan Struktur Kota dan Fleksibilitas Lokasi Permukiman Akibat Teknologi Informasi

\begin{tabular}{|c|c|c|}
\hline $\begin{array}{c}\text { A Hypothetical Metropolitan } \\
\text { Setting }\end{array}$ & $\begin{array}{l}\text { The Existing Level of } \\
\text { Residential Location Flexibility }\end{array}$ & $\begin{array}{l}\text { Residential Location Flexibility } \\
\text { In The Future }\end{array}$ \\
\hline & & 7 \\
\hline $\begin{array}{l}\text { 1. Pusat Kota } \\
\text { 2. near suburbs } \\
\text { 3. far suburbs } \\
\text { 4. exurban area } \\
\text { 5. rural area }\end{array}$ & $\begin{array}{l}\text { Lokasi yang } \\
\text { memungkinkan rumah } \\
\text { tangga bukan hanya } \\
\text { mengandalkan kendaraan, } \\
\text { tetapi juga yang } \\
\text { mengandalkan transit } \\
\text { untuk mendapatkan } \\
\text { kebutuhan akses minimum } \\
\text { Lokasi yang }\end{array}$ & $\begin{array}{l}\text { Lokasi yang } \\
\text { memungkinkan rumah } \\
\text { tangga dengan kemampuan } \\
\text { telekomunikasi, } \\
\text { mengandalkan kendaraan } \\
\text { dan juga rumah tangga } \\
\text { yang memiliki kemampuan } \\
\text { telekomunikasi dan } \\
\text { mengandalkan transit, } \\
\text { untuk memenuhi }\end{array}$ \\
\hline
\end{tabular}




\begin{tabular}{|l|l|l|}
\hline & $\begin{array}{l}\text { memungkinkan rumah } \\
\text { tangga bukan hanya } \\
\text { mengandalkan kendaraan } \\
\text { untuk mendapatkan } \\
\text { kebutuhan akses minimum }\end{array}$ & $\begin{array}{l}\text { kebutuhan akses minimum } \\
\text { Lokasi yang } \\
\text { memungkinkan rumah } \\
\text { tangga dengan kemampuan } \\
\text { telekomunikasi dan } \\
\end{array}$ \\
& $\begin{array}{l}\text { mengandalkan kendaraan } \\
\text { untuk memenuhi } \\
\text { kebutuhan akses minimum }\end{array}$ \\
\hline
\end{tabular}

\section{Dampak Terhadap Sistem Transportasi Perkotaan}

Talvetie (2003), Höjer (2000) menyatakan bahwa teknologi informasi membawa dampak tidak langsung terhadap kebutuhan transportasi misalnya akibat perubahan guna lahan dan bentuk aktivitas masyarakat. Teleworking akan mempengaruhi perilaku perjalanan. Kebutuhan transportasi memang akan mengalami perubahan, tetapi masih sulit untuk diprediksi bentuk dari perubahan tersebut. Masyarakat harus mempelajari keuntungan dan kerugian adanya kemajuan teknologi informasi. Adanya kebutuhan manusia untuk bertatap muka memastikan bahwa semua jenis teknologi informasi tidak bisa mengantikannya (Talvetie, 2003). Pengaruh Kemajuan Teknologi Informasi dalam Perspektif Perencana Transportasi memiliki beberapa keuntungan, diantaranya: Mengurangi total jam perjalanan (vehicle miles travelled) dan intensitas pada jam puncak; konsumsi energi; peningkatan jam puncak untuk transit; mengurangi biaya pemeliharaan infrastruktur dan kebutuhan ekspansi; Kemungkinan mitigasi tekanan akibat perbedaan guna lahan; Mitigasi kemacetan dan pencemaran udara; Mengurangi kecelakaan lalu lintas dan biaya sosial-ekonomi; Kemungkinan penurunan pemeliharaan infrastruktur lokal.

Sedangkan beberapa isu atau pertimbangan yang harus diperhatikan dalam sistem transportasi yaitu: Ketidakpastian mengenai skala keuntungan bagi sektor transportasi; Ketidakpastian apakah benar-benar bisa mengatasi kemacetan; Tidak diketehui dampak terhadap penggunaan kendaraan pribadi dan kebutuhan transit; Kemungkinan lokasi permukiman akan bergeser menjauhi pusat kota (http://ntl.bts.gov/DOCS/telecommute. $\underline{h t m l)}$.

Castells berargumen bahwa disagregasi tenaga kerja dan kemunculan jaringan bisnis virtual sebagai indikasi kemajuan teknologi informasi, membawa berbagai dampak terhadap bentuk perkotaan dan sosial-spasial, termasuk di dalamnya: Meningkatnya jumlah pekerja fleksibel-waktu (wirawasta atau pekerja paruh waktu); Penyebaran mobile offices; teleshopping dan peningkatan layanan antar telecommuting; intelligent routing, dispatching, dan order tracking; telemedicine; belajar jarak jauh; Perubahan nilai kepentingan lokasi lokal (renewed importance of local place) .

Castells mendukung teori yang menyatakan adanya daya dispersi dan konsentrasi yang simultan. Lima dampak pertama di atas akan menaikan travel demand, mobilitas dan potensi kemacetan lalu lintas. Castells berargumen bahwa adanya perubahan nilai mengenai tempat yang penting untuk dikunjungi sehingga banyak orang akan berhenti di banyak tempat yang berbeda yang meningkatkan mobilitas, terutama karena adanya kelonggaran dalam waktu kerja, jadwal dan jaringan sosial. Karena waktu menjadi fleksibel, lokasi aktivitas menjadi lebih khusus (singular) dan selalu mencari kekhususannya.

Menurut Mokhtarian, Handy dan Salomon (1995), efek telekomuting harus dianalisa berdasarkan jumlah total perjalanan harian, bukan hanya dengan mengamati perjalanan ke tempat bekerja. Sebagai gambaran, efisiensi rangkaian perjalanan (ke tempat kerja, 
mengantar anak sekolah, belanja dan seterusnya) akan menurun jika tidak ada perjalanan ke tempat kerja dan pola baru ini memiliki efisiensi yang lebih rendah. Pola perjalanan suatu keluarga juga akan berubah. "Penggunaan fasilitas telekomunikasi juga diharapkan dapat menurunkan intensitas keterhubungan antara tenaga kerja dan aktivitas ekonomi yang ditandai dengan adanya perubahan frekuensi perjalanan. Tetapi beberapa hal tidak bisa dilayani oleh jaringan telekomunikasi. Kebutuhan pekerja untuk aktivitas produksi dan pemeliharaan, sehingga secara fisik harus ada didekat objek produksi dan pemeliharaan tersebut (misalnya pabrik dan bengkel), menghalangi terjadinya subtitusi perjalanan oleh telekomunikasi” (Kumar, 1989).

Teknologi informasi dan komunikasi meningkat penggunaannya secara cepat dan mempengaruhi interaksi secara spasial. Ada dua efek terhadap transportasi yaitu: (1) Telekomunikasi secara parsial menggantikan kebutuhan perjalanan ke tempat kerja dan tujuan lainnya (2) Tetapi seringkali secara tidak langsung, telekomunikasi bisa merangsang pertumbuhan aktivitas baru dan menghasilkan perjalanan ekstra.

Akan tetapi, karena teleworking, teleshopping, dan telesocializing merupakan opsi baru, maka belum ada bukti empiris bahwa telekomunikasi yang dapat mempengaruhi pola spasial perkembangan permukiman. Fakta pada beberapa responden justru menunjukkan bahwa telecommuter tidak memilih untuk melakukan perjalanan dalam jarak yang lebih jauh (Pendyala et al, 1991) dan tidak menunjukkan kecenderungan yang jelas bahwa mereka akan memilih tempat tinggal jauh dari tempat bekerja (Nilles, 1991). Tetapi bagaimanapun, sampai saat ini belum ada peneliti yang bisa memerikan alasan persuasif untuk tidak mengharapkan telekomunikasi bisa mendorong desentrasisasi dalam jangka panjang.

Salomon membahas mengenai dampak telekomunikasi terhadap struktur kota. Ia memprediksikan bahwa keuntungan dan biaya telekomunikasi sangat bervariasi. Ia juga memprediksikan bahwa sentralisasi dan aglomerasi ekonomi akan memainkan peranan penting dalam pemilihan lokasi dan berpendapat bahwa telekomunikasi hanya akan memiliki efek marginal karena pemilihan lokasi ditentukan oleh sejumlah kecil eleman yang fleksibel pada jaringan spasial (misalnya bandara).

Salomon mengidentifikasi tiga hipotesa utama dalam hubungan antara telekomunikasi dan transportasi, yaitu substitusi, memperbaiki dan komplementer, dan ia berusaha mencari bukti untuk mendukung hipotesisnya ini. Salomon mendiskusikan mengenai dampak telekomunikasi terhadap bentuk kawasan perkotaan. Ia memperkirakan bahwa keuntungan dan biaya komunikasi akan bervariasi. Dia juga memperkirakan bahwa pemusatan dan aglomerasi ekonomi akan terus memainkan peranan utama dalam pemilihan lokasi dan telekomunikasi hanya memiliki efek marjinal dalam membentuk kawasan perkotaan karena pemilihan lokasi dipengaruhi oleh fleksibilitas elemen dari jaringan spasial. Ia berargumentasi bahwa struktur tenaga kerja di negara maju yang sudah unggul dalam teknologi informasi, saat ini hanya sedikit mengalami subtitusi dalam perjalanan dan tetap tergantung pada lokasi.

\section{SIMPULAN}

Dari berbagai pendapat dan penelitian yang telah dilakukan, maka dapat dibuat sebuah kesepahaman bahwa setiap kegiatan penataan kawasan perkotaan dapat merubah struktur kota dengan bentuk yang mudah diamati, namun tidak demikian halnya dengan 
teknologi informasi karena terjadinya perubahan struktur kota ini ternyata tidak menjamin akan menurunkan kebutuhan perjalanan masyarakat kota tersebut.

Selain itu, hubungan antara transportasi dan telekomunikasi lebih berupa komplementer dibandingkan dengan subtitusi. Perlu diperhatikan bahwa hipotesis tentang fungsi subtitusi teknologi informasi lebih banyak dihasilkan dari perpaduan antara usaha mencari keuntungan oleh produsen teknologi informasi dengan usaha perencana transportasi untuk mencari pemecahan masalah kemacetan dan polusi. Dengan demikian dapat disimpulkan bahwa telekomunikasi dapat memodifikasi pola perjalanan, tetapi tidak mengurangi kebutuhan akan perjalanan (travel demand).

\section{DAFTAR PUSTAKA}

Audirac, Ivonne and Fitzgerald, Jennifer. (2003). Information Technology (IT) and Urban Form: An Annotated Bibliography of the Urban Deconcentration and Economic Restructuring Literatures. Journal of Planning Literature. 17; 480 by Sage Publications.

Audirac, Ivonne. (2002). Information Technology and Urban Form. Journal of Planning Literature. 17; 212 by Sage Publications

Crane, Randall. (1996). On Form Versus Function: Will The New Urbanism Reduce Traffic, Or Increase It?. Journal of Planning Education and Research. University of California, Irvme, Calzfornza 92717- 5150 Usa.

Hjorthol, Randi and Nossum, Åse. (2008). Teleworking: a reduction in travel or just increased flexibility?. Institute of Transport Economics, Norwegian Centre for Transport Research, Norway, The Journal of E-working Pages 81-94, Vol 2.

Meshur, M. Caglar. (2007). New Information And Communication Technologies (NICTS) And Changing Urban Areas Regarding Sustainability. Department of City and Regional Planning Selçuk University, Turkey. International Conference, Sustainable Urban Areas, Rotterdam.

Qing, Shen. (2000). New Telecommunications And Residential Location Flexibility. Department of Urban Studies and Planning, Massachusetts Institute of Technology, Cambridge, MA 02139, USA. Journal Environment and Planning A 2000 , volume 32 , pages 1445-1463.

Talvitie, Juha. (2002). The Influence of Information Technology on Spatial Development. Basical Planning Aspects and Examples. Worldwide FIG XXII International Congress. Washington, D.C. USA, April 19-26.

Yoshimoto, Ryuchi and Nemoto, Toshinori. (2005). The Impact Of Information And Communication Technology On Road Freight Transportation. IATSS RESEARCH Vol.29 No.1, 2005. 